\title{
ARE THERE ANY VARIATION IN NEUTROPHIL LYMPHOCYTE RATIO, MEAN PLATELET VOLUME AND PLATELET COUNT BETWEEN PAPILLARY THYROID CANCER AND BENIGN NODULAR THYROID DISEASES
}

\author{
Sengul Demet, ${ }^{1}$ Sengul Ilker ${ }^{2}$ \\ ${ }^{1}$ Department of Pathology, Giresun University Faculty of Medicine, Giresun, Turkey \\ ${ }^{2}$ Division of Endocrine Surgery, Department of General Surgery, \\ Giresun University Faculty of Medicine, Giresun, Turkey
}

Primljen/Received 07. 03. 2018. god.

Abstract: Objective: Neutrophil lymphocyte ratio (N/L) and mean platelet (Plt) volume (MPV), the markers of systemic inflammatory response, has been investigated in many cancers, but data for the head and neck cancers and thyroid carcinoma are limited. It had been purposed to study N/L, MPV, and Plt levels in papillary thyroid carcinoma (PTC) as a diagnostic marker. Material and Methods: A total of 104 patients, had undergone ultrasonography guided fine needle aspiration (FNA) and thyroidectomy, for the indicated cases, between April 2010 and August 2013, were enrolled in the study. The laboratory tests, regarding $\mathrm{N} / \mathrm{L}$, MPV, and Plt, of the cases had been collected retrospectively. Results: No difference was found between PTC and benign nodular thyroid diseases (BNTD) in terms of age, gender, size of the nodule, N/L, MPV, and Plt $(p>0.05)$. Conclusion: The preoperative inflammatory hematological parameters, in terms of $\mathrm{N} / \mathrm{L}$, MPV, and Plt, may not be useful as a predictive diagnostic marker of the thyroid malignancy, PTC.

Key words: Thyroid neoplasms, Papillary thyroid cancer (PTC), Ultrasonography (US), Ultrasonography guided fine needle aspiration (US-g-FNA), Bethesda, Neutrophils, Lymphocytes, Neutrophil lymphocyte ratio, Mean platelet volume (MPV), Blood platelets.

\section{INTRODUCTION}

Thyroid cancer, the most common endocrine cancer, that has the dramatically increased incidence worldwide in terms of new diagnosis and mortality with the significant change in the papillary histotype (1-5). The shortage of the clically proven markers in the diag-
Prihvaćen/Accepted 06. 04. 2018. god.

nosis of thyroid cancers like the other head and neck cancers still sustains the adversity in absolute and definitive preoperative diagnosis in the field of Neck-Endocrine Surgery. Many studies established the augmentation of neutrophil lymphocyte ratio $(\mathrm{N} / \mathrm{L})$ and mean platelet (Plt) volume (MPV), the markers of systemic inflammatory response, being related with the progression and survival of the certain types of cancers $(6,7)$.

In the present study, the laboratory tests of the patients that have thyroid nodules have been evaluated retrospectively and the relationship between papillary thyroid cancer (PTC) and the inflammatory hematological parameters including N/L, MPV, and Plt had been investigated.

\section{MATERIAL AND METHODS}

A retrospective analysis comprised of the patients that posses the nodular thyroid disease, who had undergone one-endocrine surgeon performed ultrasonography (US) guided fine needle aspiration (FNA) between April 2010 and August 2013. The documents were consisting the complete blood counts and US guided FNA (US-g-FNA) cytologies (FNACs) which had been reported according the guidance of The Bethesda System for Reporting Thyroid Cytopathology (TBSRTC), a 6-diagnostic-category system which was constituted through multidisciplinary formulation, which was proposed at the National Cancer Institute (NCI) Thyroid Fine Needle Aspiration State of the Art and Science Conference held in Bethesda, Maryland, 2007. TBSRTC is at present the most used and accepted reporting system 
for reporting FNA cytology worlwide (8). The use of TBSRTC has also been endorsed by 2015 American Thyroid Association (ATA) management guidelines (9) as 2009 ATA guidelines (10) which is a revision of 2006 ATA guidelines (11). However, a special 2\%1/2-hour symposium entitled 'The Bethesda System for reporting thyroid cytopathology: past, present', future was moderated by Ali and Vielh at The 19th International Congress of Cytology (ICC) in Pacifico Yokohama, Japan, on 28 May-01 June, 2016 (12, 13). Pusztaszeri et al (14). Ali et al $(12,13)$ also discussed briefly the concensus of panel, recommendations, proposed modifications and updates for the second edition, TBSRTC II (12) by anticipating the second edition of TBSRTC, TBSRTC II, in early 2018.

As a result, cases were divided into two groups, benign nodular thyroid diseases (BNTD), diagnosed by the current TBSRTC I Class II as Group 1and PTC whose diagnoses also had been verified histopathologically as Group 2. They were taken into account if the age, gender, size of the tumor had ben correlated to the inflammatory hematological parameters regarding N/L, MPV, and Plt.

\section{The Criteria for Incorporation into the Study}

The screening outcome revealed the 104 cases in conformity with the criteria for being incorporated into the study. 95 cases with BNTD and 9 cases with PTC had been enrolled the present study between April 2010 and August 2013 by excluding the hematologic disorders, cardiac disorders, autoimmune diseases, inflammatory or infective diseases, endocrinologic diseases and diabetes, the patients with the elevated thyroid antibodies or impaired thyroid function tests, liver diseases, renal failure, recurrent disases, previous or accompanying other malignancies, as well as those who had medical records as to the usage of steroids, anticoagulants, and alcohol along with those with a medical history of hepatitis.

\section{Statistical Analysis}

The statistical analysis were performed by using SPSS 23.0 computer program. The Fisher Exact Test was applied for gender parameter. The Mann Whitney U-tests were applied for MPV, N/L and size parameters due to the samples not being obtained from normal population according to Kolmogorov-Simirnov and Shapiro Wilk Normality tests. The Independent sample t-tests were used to detect difference among two groups for age and Plt parameters and $p$ value less than 0.05 was considered as statistically significant.

\section{RESULTS}

$9(8.65 \%)$ out of 104 cases possesing thyroid nodules (male/female: 15/89, 10.41\%/61.8\%) had PTC, while $95(91.35 \%)$ had BNTD. It had not been detected any statistically significant difference between the cases with BNTD, Group 1 and cases with PTC, Group 2 in terms of age, gender, size of the nodule, N/L, MPV, and Plt $(\mathrm{p}>0.05)$ (Figure 1a-f). Therefore, according to the statistical test results, there was no difference between PTC and benign thyroid nodules for all the parameters (Table 1).

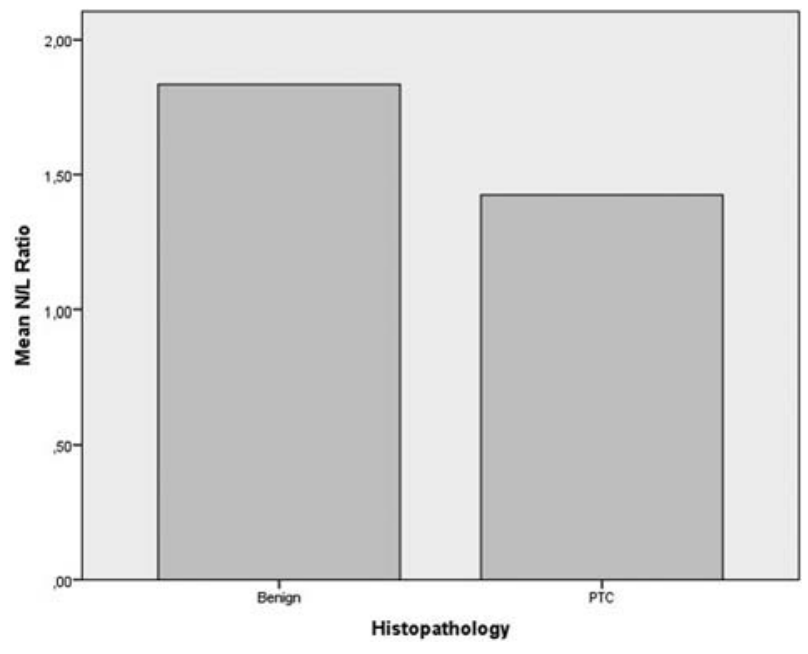

Figure 1a: The median N/L from PTC and Control group

Table 1 - The comparison of demographic features and hematological paramaters between the patients with benign nodular thyroid disease and PTC

\begin{tabular}{|l|c|c|c|}
\hline \multicolumn{1}{|c|}{ Parameters } & Benign & PTC & p Value \\
\hline MPV, femtoliters, $\mathrm{fL}$ & $191 \mp 262$ & $172 \mp 234$ & 0,470 \\
\hline Plt $\left.\mathrm{x} 10^{9} / \mathrm{L}\right)$ & $271 \mp 56$ & $280 \mp 66$ & 0,649 \\
\hline $\mathrm{N} \backslash \mathrm{L}$ & $1,8 \mp 0,8$ & $1,4 \mp 0,4$ & 0,051 \\
\hline Age, year & $50 \mp 12$ & $53 \mp 9$ & 0,565 \\
\hline Size, $\mathrm{mm}$ & $18 \mp 9$ & $19 \mp 10$ & 0,728 \\
\hline Gender, male/female & $15 / 80$ & $0 / 9$ & 0,351 \\
\hline
\end{tabular}

PTC, papillary thyroid carcinoma; MPV, mean platelet volume; Plt, platelet; N/L; neutrophil lymphocyte ratio; Size, size of the nodule 


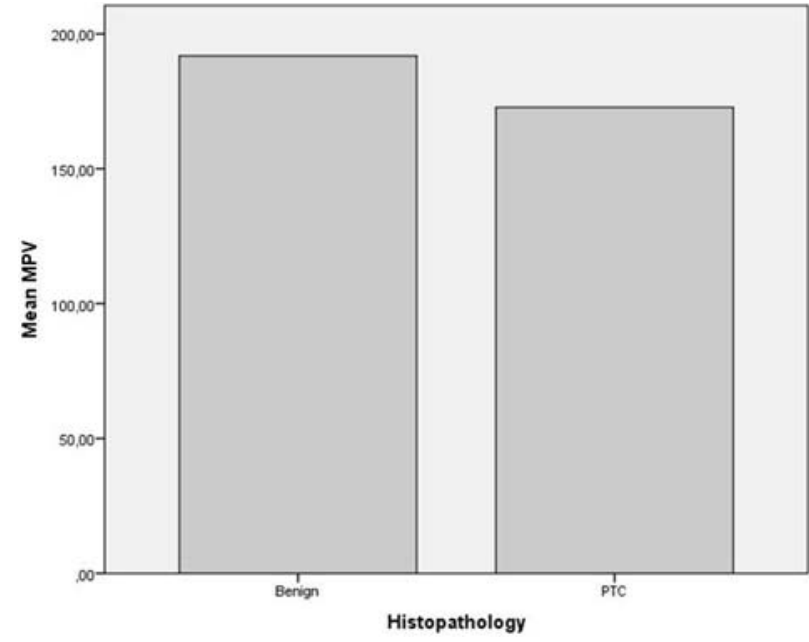

Figure $1 \boldsymbol{b}$ - The median MPV from PTC and Control group

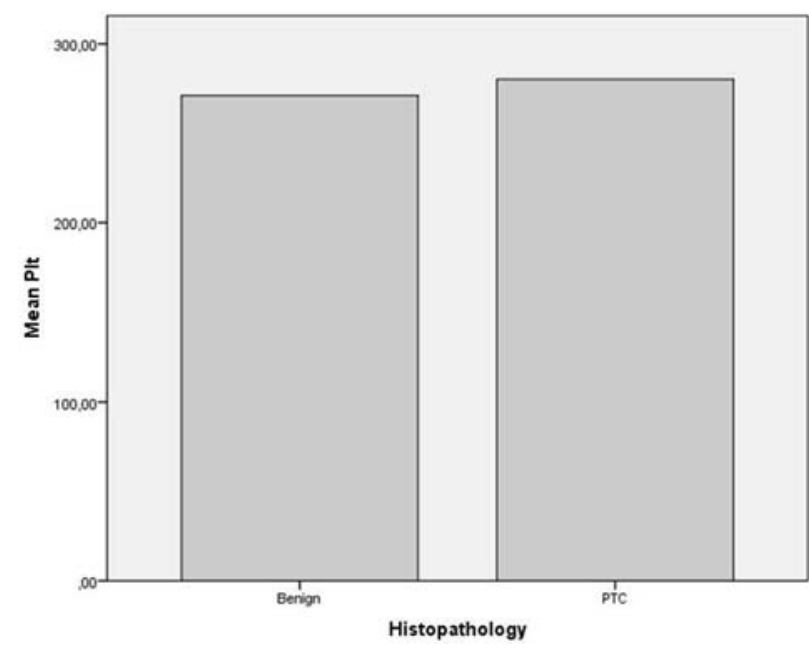

Figure 1c - The median Plt from PTC and Control group

\section{DISCUSSION}

As a common clinical problem, the thyroid nodules, reveal the prevalance of approximately $5 \%$ in women and $1 \%$ in man living in iodine-sufficient areas of the world epidemiologically in palpation, whereas $19 \%-68 \%$ is the detection rate in high resolution US, with higher frequencies in women and elderly (9). The thyroid nodules are important clinically as long as eliminating the thyroid cancer comprising $7 \%-15 \%$ of the cases being based on age, sex, radiation exposure history to head and neck and thorax, particularly during first two decades, family history, and the other factors $(15,16)$.

Differentiated thyroid cancer (DTC), consisting PTC, follicular thyroid carcinoma (FTC), and Hurthle cell carcinoma (HCC), constitutes vast majority, $>90 \%$, of the thyroid cancers (17). In the United States, the yearly incidence of thyroid cancer has nearly tripled from 4.9 per 100,000 in 1975 to 14.3 per 100,000 in

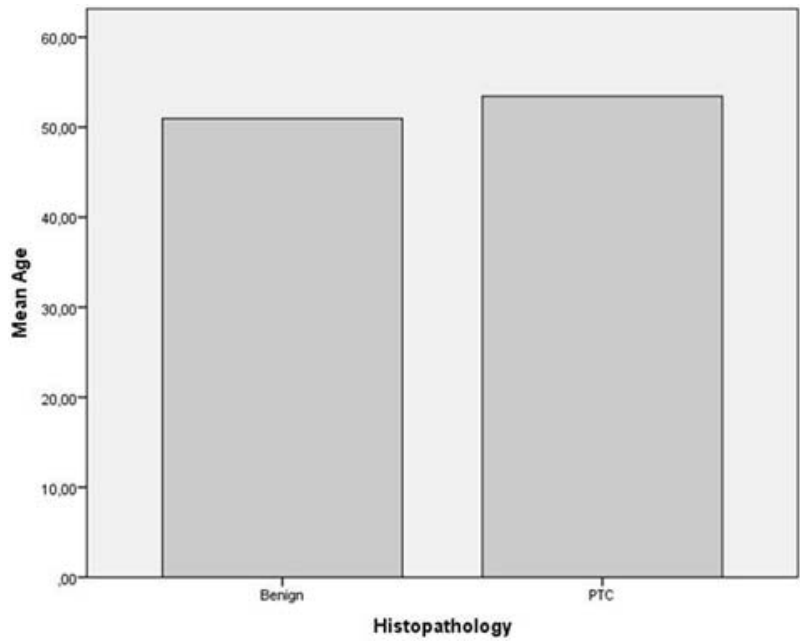

Figure 1d - The median age from PTC and Control group

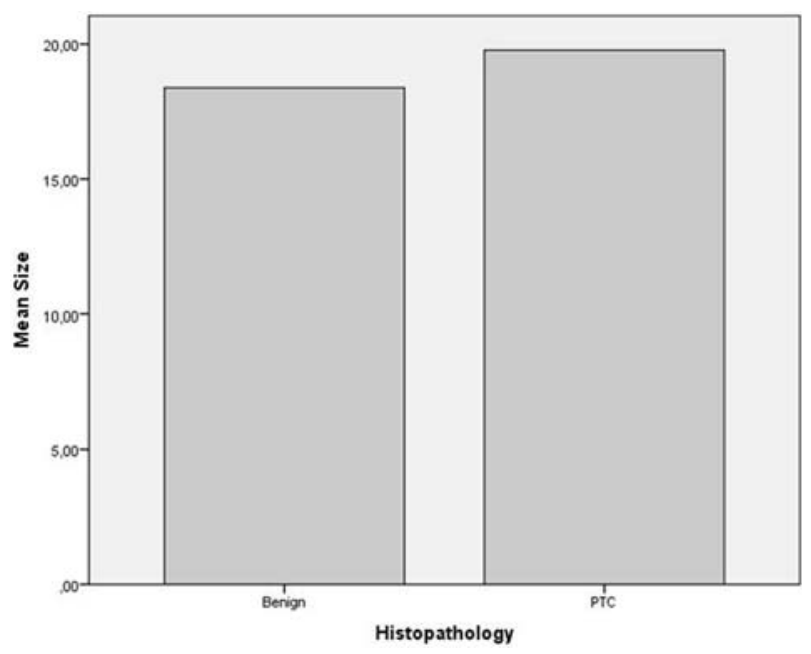

Figure 1e - The median size of the nodule from PTC and Control group

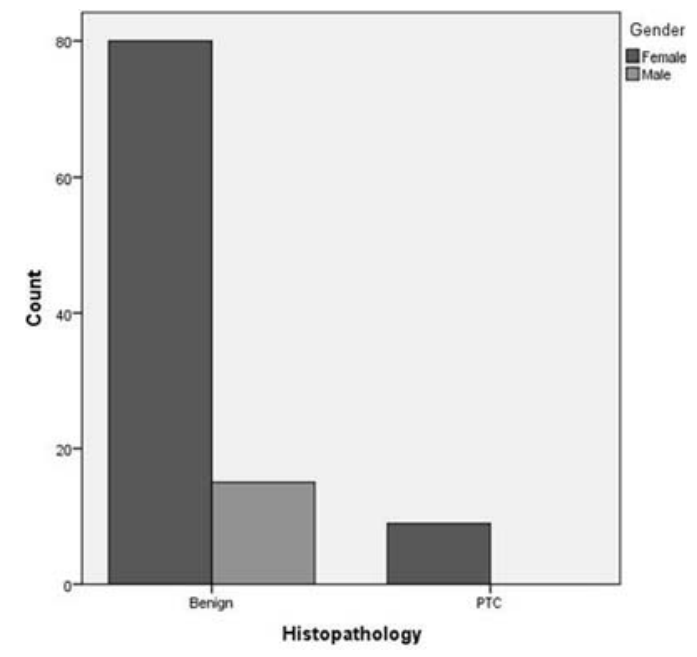

Figure $1 \boldsymbol{f}$ - The numerical value of gender from PTC and Control group

2009 and virtually the entire change has been attributed to an increase in the incidence of papillary thyroid cancer $(18,19)$. One study estimates PTC will being 
become the third most common cancer in women at a cost of \$19-21 billion in the United States (20).

$\mathrm{N} / \mathrm{L}$, known as marker of systemic inflammatory response, have been associated with progression and survival in most kind of cancers $(6,7)$. Chang et al $(21)$ found $\mathrm{N} / \mathrm{L}, \mathrm{Hb}$, and Plt count beneficial for predicting long-term mortality in cases with nasopharyngeal carcinoma. N/L estimated as a negative indicator for oral cancer (22), breast cancer (23), and pancreatic adenocarcinoma (24). Feng et al (25) reported in a pilot study the elevated levels of N/L in cases with papillary thyroid microcarcinoma (PTmC) and PTC. Hower, N/L was not statistically different the patients with BNTD and PTC, in the present study. Similiar to the present study, Liu et al (26) reported a metanalysis on December 2016 to be able to clarify the undecided association between N/L and DTC. They conducted a systematic meta-analysis based on 7 prospective cohort studies published between 2013 and 2015, to investigate a potential association between N/L and DTC comprising 7349 patients. It was not detected any significant difference in $\mathrm{N} / \mathrm{R}$ between the patients with benign nodules and PTC aged $<45$ years and those aged $\geq 45$ years, similar to our study.

Larger platelets are more metabolically and enzymatically active than the smaller ones. MPV reflects platelet activity indicating being an important biological variable (26). In a Turkish study, MPV was suggested as a possible biomarker in the diagnosis of PTC and estimator for therapeutic effectiveness in PTC in terms of its attenuated postoperative levels (27). However, we haven't detected significant difference between the groups, BNTD and PTC, in terms of MCV and Plt.

\section{CONCLUSION}

The present study lasted approximately three and a half years. However, a retrospective design, a relatively low sample count, not analyzing postoperative values of hematologic parameters and not comparing them with the preoperative ones were the limitations of the present study.

In conclusion, preoperative N/L, MPV, and Plt levels may not be useful as a predictive diagnostic marker of thyroid malignancy, PTC, in contrast to the rela- ted investigation. However, further studies with larger groups in multidicipliner and multicentric studies may reveal the different results in the future.

\section{Conflict of interest}

No any conflict of interest relevant to this article was declared.

\section{Acknowledgements}

It has not been used any funding for the present work. DS had contributed in constituting the notion and hypothesis, intellectual planning and management of the study, collecting the data, performing the statistical analysis, writing the whole manuscript, its linguistic and academical revisions. IS had contributed in examining the patients and performing US-guided-FNA for each indicated thyroid nodule, collecting the data, academical revision of the manuscript. All the authors finally approved the submitted and proof versions without any conflict of interest.

We would like to thank the resident and students of Department of General Surgery and all the staff and personnel of Department of Pathology, Giresun University-Ministery of Health Prof. Dr. A. Ilhan Ozdemir Education and Research Hospital, Giresun, Turkey.
Abreviations
N/L - Neutrophil lymphocyte ratio
MPV - Mean platelet volume
PIt - Platelet
PTC - Papillary thyroid cancer
BNTD - Benign nodular thyroid diseases
DTC - Differentiated thyroid cancer
FTC - Follicular thyroid carcinoma
HCC - Hurthle cell carcinoma
US - Ultrasonography
FNA - Fine needle aspiration
US-g-FNA - US guided FNA
FNAC - FNA cytology
TBSRT - The Bethesda System for Reporting Thyroid Cytopathology
ATA - American Thyroid Association 


\title{
Sažetak
}

\section{DALI POSTOJE VARIJACIJE U ODNOSU NEUTROFILAI LIMFOCITA, SREDNJEG VOLUMENA TROMBOCITA I BROJA TROMBOCITA IZMEĐU PAPILARNOG TIROIDNOG KARCINOMAI BENIGNOG NODULARNOG POREMEĆAJA ŠTITNE ŽLEZDE?}

\author{
Sengul Demet, ${ }^{1}$ Sengul Ilker ${ }^{2}$ \\ ${ }^{1}$ Department of Pathology, Giresun University Faculty of Medicine, Giresun, Turkey \\ 2 Division of Endocrine Surgery, Department of General Surgery, \\ Giresun University Faculty of Medicine, Giresun, Turkey
}

Uvod: Odnos neutrofila i limfocita (N/L) i srednjeg volumena trombocita (MPV), markeri sistemskog inflamatornog odgovora, istraživani su u mnogim karcinomima, ali podaci o karcinomima glave i vrata i tiroidnom karcinomu su ograničeni. Cilj ove studije bio je da se izuči povezanost N/L, MPV, Plt niova u papilarnom karcinomu tireoidne žlezde (PTC) kao dijagnostičkog markera.

Materijal i metode: Ukupno 104 pacijenta koja su bila podvrgnuta ultrasonografski vođenoj biopsiji pomoću tanke igle (FNA) i tireoidektomiji za slučajeve kod kojih je to indikovano uključeni su u studiju u periodu između aprila 2010. i avgusta 2013. godine. Podaci o laboratorijskim analizama, koje uključuju N/L odnos, MPV, Plt bili su sakupljani retrospektivno.

\section{REFERENCES}

1. Hegedüs L. Thyroid size determined by ultrasound. Influence of physiological factors and non-thyroidal disease. Dan Med Bull. 1990; 37(3): 249-63.

2. National Cancer Institute. A snapshot of thyroid cancer; 2015 [Internet]. Bethesda (MD): National Cancer Institute; [posted 2014 Nov 5] Available from: www.cancer.gov/researchandfunding/ snapshots/thyroid.

3. Pacini F, Schlumberger M, Dralle H, Elisei R, Smit JW, Wiersinga $\mathrm{W}$ et al. European consensus for the management of patients with differentiated thyroid carcinoma of the follicular epithelium. Eur J Endocrinol. 2006; 154(6): 787-803.

4. Pellegriti G, Frasca F, Regalbuto C, Squatrito S, Vigneri $\mathrm{R}$. Worldwide increasing incidence of thyroid cancer: update on epidemiology and risk factors. J Cancer Epidemiol. 2013; 2013: 965212.

5. Cramer JD, Fu P, Harth KC, Margevicius S, Wilhelm SM. Analysis of the rising incidence of thyroid cancer using the Surveillance, Epidemiology and End Results national cancer data registry. Surgery. 2010; 148(6): 1147-52.

6. Hanahan D, Weinberg RA. The hallmarks of cancer Cell. 2000; 100(1): 57-70.

7. Hanahan D, Weinberg RA. Hallmarks of cancer: the next generation. Cell. 2011; 144(5): 646-74.

8. Cibas ES, Ali SZ. The Bethesda system for reporting thyroid cytopathology. Thyroid. 2009; 19(11): 1159-65.

9. Haugen BR, Alexander EK, Bible KC, Doherty GM, Mandel SJ, Nikiforov YE, et al. 2015 American thyroid association management guidelines for adult patients with thyroid nodules and differentiated thyroid cancer: The American thyroid
Rezultati: Nije postojala statistički značajna razika između PTC i benignog nodularnog poremećaja štitaste žlezde u pogledu godina, pola, veličine nodula, N/L, MPV i Plt ( $p>0.05)$.

Zaključak: Preoperativni inflamatorni hematološki parametri, kao što su N/L, MPV i Plt nisu upotrebljivi kao prediktivni dijagnostički markeri tireoidnog maligniteta, PTC.

Ključne reči: tireoidna neoplazma, papilarni tireoidni karcinom (PTC), ultrasonografija, ultrasonografski vođena biopsija tankom iglom, bethesda, neutrofili, limfociti, odnos neutrofila i limfocita, srednja vrednost volumena trombocita, trombociti.

sssociation guidelines task force on thyroid nodules and differentiated thyroid cancer. Thyroid. 2016; 26(1): 1-33.

10. American Thyroid Association (ATA) Guidelines Taskforce on Thyroid Nodules and Differentiated Thyroid Cancer, Cooper DS, Doherty GM, Haugen BR, Kloos RT, Lee SL, et al. Revised American Thyroid Association management guidelines for patients with thyroid nodules and differentiated thyroid cancer. Thyroid. 2009; 19(11): 1167-214.

11. Cooper DS, Doherty GM, Haugen BR, Kloos RT, Lee SL, Mandel SJ et al. Management guidelines for patients with thyroid nodules and differentiated thyroid cancer. Thyroid. 2006, 16(2): 109-42.

12. Ali SZ, Vielh P, Pusztaszeri M, Rossi D, Faquin WC, Bishop JA, et al. The Bethesda System for reporting thyroid cytopathology: past, present, future at The 19th International Congress of Cytology in Pacifico Yokohama, Japan, on 28 May-01 June, 2016, Symposiunm 12.

13. Ali SZ, Cibas ES. The Bethesda system for reporting thyroid cytopathology II. Acta Cytol. 2016; 60(5): 397-8.

14. Pusztaszeri M, Rossi ED, Auger M, Baloch Z, Bishop J, Bongiovanni M, et al. The Bethesda system for reporting thyroid cytopathology: proposed modifications and updates for the decond edition from an international panel. Acta Cytol. 2016; 60(5): 399-405.

15. Hegedüs L Clinical practice. The thyroid nodule. N Engl J Med. 2004; 351(17): 1764-71.

16. Mandel SJ A 64-year-old woman with a thyroid nodule. JAMA. 2004; 292(21): 2632-42.

17. Sherman SI Thyroid carcinoma. Lancet 2003; 361(9356): 501-11. 
18. Siegel R, Ma J, Zou Z, Jemal A Cancer statistics, 2014 CA Cancer J Clin. 2014; 64(1): 9-29.

19. Davies L, Welch HG. Current thyroid cancer trends in the United States. JAMA Otolaryngol Head Neck Surg. 2014; 140(4): 317-22.

20. Aschebrook-Kilfoy B, Schechter RB, Shih YC, Kaplan EL, Chiu BC, Angelos P, et al. The clinical and economic burden of a sustained increase in thyroid cancer incidence. Cancer Epidemiol Biomarkers Prev. 2013; 22(7): 1252-9.

21. Chang H, Gao J, Xu BQ, Guo SP, Lu RB, et al Haemoglobin, neutrophil to lymphocyte ratio and platele.t count improve prognosis prediction of the TNM staging system in nasopharyngeal carcinoma: development and validation in 3,237 patients from a single institution. Clin Oncol (R Coll Radiol). 2013; 25(11): 639-46.

22. Perisanidis C, Kornek G, Pöschl PW, , Holzinger D, Pirklbauer K, Schopper C et al. High neutrophil-tolymphocyte ratio is an independent marker of poor disease-specific survival in patients with oral cancer. Med Oncol. 2013; 30(1): 334.
23. Chen J, Deng Q, Pan Y, He B, Ying H, Sun H et al. Prognostic value of neutrophil-tolymphocyte ratio in breast cancer. FEBS Open Bio. 2015; 5:502-7.

24. Smith RA, Bosonnet L, Raraty M, Sutton R, Neoptolemos JP, Campbell F,et al. Preoperative platelet-lymphocyte ratio is an independent significant prognostic marker in resected pancreatic ductal adenocarcinoma. Am J Surg. 2009; 197(4): 466-72.

25. Feng JF, Huang Y, Liu JS. Combination of neutrophil lymphocyte ratio and platelet lymphocyte ratio is a useful predictor of postoperative survival in patients with esophageal squamous cell carcinoma. Onco Targets Ther. 2013; 6:1605-12.

26. Mangalpally KK, Siqueiros-Garcia A, Vaduganathan M, Dong JF, Kleiman NS, Guthikonda S. Platelet activation patterns in platelet size subpopulations: differential responses to aspirin in vitro. J Thrombosis Thrombolysis. 2010; 30(3): 251-62.

27. Baldane S, Ipekci SH, Sozen M, Kebapcilar L. Mean platelet volume could be a possible biomarker for papillary thyroid carcinomas. Asian Pac J Cancer Prev. 2015; 16(7): 2671-4.

\section{Correspondence to/Autor za korespondenciju}

Ilker SENGUL, M. D.

The Founder Vice Dean,

Associated Professor of General Surgery

The Founder Chairman, Endocrine Surgery

The Founder Chairman, General Surgery

Vice Chair, Department of Surgical Sciences

Giresun University Faculty of Medicine

The Administrative Manager,

The Founder Chairman, Program Manager of Education

General and Endocrine Surgery Clinic

Ministry of Health Giresun University-Prof. Dr. A. Ilhan Ozdemir

Education and Research Hospital

Nizamiye Compound

Mumcular Avenue

TR28100 Giresun, TURKEY

Pho Deanery: +90 (454) 3101600

Hospital: +90 (454) 3102000

GSM: +90 (507) 4804377

Fax: +90 (454) 3101699

E-mail: dr.ilker52@mynet.com

ilker.sengul@giresun.edu.tr 